\title{
"The question calls for an answer, and I propose to answer it": The Patriation Reference as Constitutional Method
}

Carissima Mathen

Follow this and additional works at: http://digitalcommons.osgoode.yorku.ca/sclr

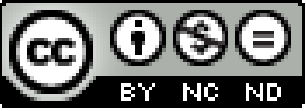

This work is licensed under a Creative Commons Attribution-Noncommercial-No Derivative Works 4.0 License.

\section{Citation Information}

Mathen, Carissima. "'The question calls for an answer, and I propose to answer it": The Patriation Reference as Constitutional Method." The Supreme Court Law Review: Osgoode's Annual Constitutional Cases Conference 54. (2011).

http://digitalcommons.osgoode.yorku.ca/sclr/vol54/iss1/6 


\title{
"The question calls for an answer, and I propose to answer it": The Patriation Reference as Constitutional Method
}

\author{
Carissima Mathen*
}

\section{INTRODUCTION}

The 30th anniversary of the Reference re Amendment of Constitution of Canada is an opportunity to reflect on Canada's constitutional tradition. In character, reasoning and outcome, the Patriation Reference seems to be quintessentially Canadian. It is of course most famous for articulating a constitutional convention requiring substantial provincial consent for amendments affecting provincial powers; and only slightly less famous for considering a question about conventions at all. Many have criticized it as a political manoeuvre that is neither supportable nor particularly subtle. ${ }^{2}$

While conventions are a fascinating topic, especially in light of recent events, ${ }^{3}$ in this paper I propose to examine the Patriation Reference in a different vein, namely, as a paradigmatic example of the reference function. In this way, I hope to evaluate its broader impact on Canadian constitutional law.

\footnotetext{
Associate Professor, Faculty of Law, University of New Brunswick; Visiting Professor of Law, University of Ottawa.

1 [1981] S.C.J. No. 58, [1981] 1 S.C.R. 753 [hereinafter "Patriation Reference"].

2 Michael Mandel, The Charter of Rights and the Legalization of Politics in Canada (Toronto: Thomson 1994), c. 1 [hereinafter "Mandel"]; Peter Russell, Constitutional Odyssey: Can Canadians Become a Sovereign People? (Toronto: University of Toronto Press, 1992), c. 8 [hereinafter "Russell"].

3 Consider, for example, the 2008 and 2009 controversies surrounding Prime Minister Harper's prorogation of Parliament, and recent debates over the workings of minority government. See Peter Russell \& Lorne Sossin, eds., Parliamentary Democracy in Crisis (Toronto: University of Toronto Press, 2009).
} 
The paper proceeds as follows. First, the Patriation Reference is situated in its legal and political context. While the reference power has an English pedigree, it quickly came to embody very Canadian characteristics. The circumstances surrounding the Patriation Reference are noteworthy, but it was not a singular event - it was the product of a specific historical trajectory. Next, I consider how some of these factors played out in the Court's opinion. In the final section, I consider questions of legacy. I argue that the Patriation Reference presaged the modern approach to constitutional interpretation which views the Constitution as a constellation of shifting interests and allegiances, with the Supreme Court as the most important arbiter of social and political questions. In my view the Reference was highly predictive of broad patterns in constitutional litigation and jurisprudence. In short, the Patriation Reference was a harbinger of the modern constitutional method.

\section{Putting A ReFERENCE ON PATRIATION INTO CONTEXT}

The reference jurisdiction is an important and distinguishing feature of the Canadian Constitution. It commonly is cited as a key difference between Canada and the United States, where the federal Constitution permits the judiciary to decide only "cases and controversies". ${ }^{4}$ As a result, U.S. federal courts do not hear references. ${ }^{5}$ In contrast, Canadian constitutionalism appears to view the judiciary, at least in part, as an office of the Crown, and occasionally "the official adviser of the executive". 6

\footnotetext{
4 U.S. Constitution, Art. III, s. 2. In addition, the U.S. Constitution provides for a "supreme court" in which shall be invested "the judicial power of the United States". U.S. Const., Art.3, $\S 1$. The Canadian Constitution contains no equivalent provision. The Supreme Court of Canada is established by a federal statute, the Supreme Court Act, R.S.C. 1985, c. S-26, which implies that the Court could be eliminated by an ordinary Act of Parliament. I recognize that there is ambiguity on this point because of s. 41(d) of the Constitution Act, 1982, being Schedule B to the Canada Act 1982 (U.K.), 1982, c. 11, which includes a change to "the composition of the Supreme Court" as one of the matters requiring a unanimous constitutional amendment.

$5 \quad$ Muskrat v. United States, 219 U.S. 346, at 362 (1911). Some state constitutions do allow for advisory opinions. However, Lawrence Tribe writes that even in such states the courts generally describe the advisory opinion as "extrajudicial" and possessed of "dramatically limited stare decisis effect": Lawrence Tribe, American Constitutional Law (Mineola: The Foundation Press, 1988), at 73, n. 4. See generally Note, "Advisory Opinions on the Constitutionality of Statutes" (1956) 69 Harv. L. Rev. 1302.

${ }_{6}$ In re References by the Governor-General in Council, [1910] S.C.J. No. 33, 43 S.C.R. 536, at 547, affd [1912] A.C. 571 (P.C.). [hereinafter "Reference re References"].
} 
Canada's different path is rooted in English law which first incorporated a reference power in the Judicial Committee Act of $1833{ }^{7}$ section 4 of which authorized the Crown to refer for consideration "any such matters whatsoever as His Majesty shall think fit". ${ }^{8}$ Section 4 almost certainly was the model for the inclusion, in 1875, of a similar power in Canada's Supreme and Exchequer Court Act: ${ }^{9}$

52. It shall be lawful for the Governor in Council to refer to the Supreme Court for hearing or consideration, any matters whatsoever as he may think fit; and the Court shall thereupon hear and consider the same and certify their opinion thereon to the Governor in Council: Provided that any Judge or Judges of the said Court who may differ from the opinion of the majority may in like manner certify his or their opinion or opinions to the Governor in Council. ${ }^{10}$

Section 52 soon proved inadequate because the Supreme Court took the view that it need only state a bare answer without reasons. ${ }^{11}$ Depending on the specificity of the question, this obviously could fail to provide suitable guidance. For example, in the McCarthy Act Reference ${ }^{12}$ the Supreme Court found a federal liquor law to be ultra vires without explaining why, thus leaving the federal government without a sufficient basis to know how to proceed.

The situation was deemed unacceptable, and the Act was amended in 1891. Many of the changes made survive to the present day. The Court was to "hear and consider [the reference], and to answer each question so referred"; and to certify "its opinion upon each such question, with the reasons for each such answer". The opinion was to be "pronounced in like manner as in the case of a judgment upon an appeal to the Court"; and any dissenting opinions were to be recorded. The Act elaborated, as well, on the questions that could be put to the Court:

\footnotetext{
$3 \& 4 \mathrm{Wm} . \mathrm{IV}$, c. 41

As discussed in Barry L. Strayer, The Canadian Constitution and the Courts (Toronto: Butterworths, 1988), at 311 [hereinafter "Strayer"].

$9 \quad$ S.C., 1875 , c. 11.

10 Id., s. 52. Section 53 provided a similar power for either chamber of the House of Commons to refer private bills. While it survives to the present day (see Supreme Court Act, R.S.C. 1985, c. S-26, s. 54), this second reference power has fallen into disuse. In my opinion, this is unfortunate. Strayer, supra, note 8 , at 312 . In fairness, the J.C.P.C. apparently agreed, which, given the history of references in England, is difficult to explain.

12 Sess. Papers No. 85a, 1885 (Can.), at 12-13.
} 
Important questions of law or fact touching

(a) the interpretation of the "British North America Acts," 1867 to 1886 ; or

(b) The constitutionality or interpretation of any Dominion or provincial legislation; or,

(c) The appellate jurisdiction as to educational matters, by the "British North America Act, 1867," or by any other Act or law vested in the Governor in Council; or,

(d) The powers of the Parliament of Canada, or of the legislatures of the provinces, or of the respective governments thereof, whether or not the particular power in question has been or is proposed to be executed; or,

(e) Any other matter ... with reference to which the Governor in Council sees fit to submit any such question ...

Where a reference concerned the validity of provincial legislation, "the government of any province [had a] special interest in any such question, [and] the Attorney-General of such province [would] be notified of the hearing." The Court also could notify any parties it thought fit to be present. The one element in 1891 that was subsequently abandoned was a clause deeming opinions to be "advisory only". For all purposes of appeal, though, the opinion was to be treated as a final judgment. ${ }^{13}$

13 S.C. 1891 , c. 25 , s. 4. The relevant provision today (Supreme Court Act, R.S.C. 1985, c. S-26) is largely similar, although the reference to the Court's opinion being merely "advisory" has been removed:

53(1) The Governor in Council may refer to the Court for hearing and consideration important questions of law or fact concerning

(a) the interpretation of the Constitution Acts;

(b) the constitutionality or interpretation of any federal or provincial legislation;

(c) the appellate jurisdiction respecting educational matters, by the Constitution Act, 1867 , or by any other Act or law vested in the Governor in Council; or

(d) the powers of the Parliament of Canada, or of the legislatures of the provinces, or of the respective governments thereof, whether or not the particular power in question has been or is proposed to be exercised.

(2) The Governor in Council may refer to the Court for hearing and consideration important questions of law or fact concerning any matter, whether or not in the opinion of the Court ejusdem generis with the enumerations contained in subsection (1), with reference to which the Governor in Council sees fit to submit any such question.

(4) Where a reference is made to the Court under subsection (1) or (2), it is the duty of the Court to hear and consider it and to answer each question so referred, and the Court shall certify to the Governor in Council, for his information, its opinion on each question, with the reasons for each answer, and the opinion shall be pronounced in like manner as 
The first challenge to the reference power came from the provinces, which viewed it as conferring an unfair federal advantage. This concern was recognized in 1891 when the Act was amended to provide for automatic notice to affected provinces, as well an automatic right to appear. Yet the provinces continued to have grave concerns, as articulated in Reference re References, ${ }^{14}$ which involved a federal question about the provincial power to incorporate companies. Six provinces contested the hearing, arguing first that it offended the division of powers for the federal government to refer questions of law concerning provincial matters; and, second, that the reference power was incompatible with the nature of a "general court of appeal" as provided for in section 101 of the Constitution Act, $1867 .{ }^{15}$

With respect to the division of powers argument, a majority of the Supreme Court held that the use in section 101 of the words "a general court of appeal" was broad enough to encompass the reference jurisdiction, and that nothing in the Constitution Act, 1867 suggested that the jurisdiction exists only with respect to questions of federal law. ${ }^{16}$ On appeal, the J.C.P.C. did not specifically canvass the argument but its reference to the numerous examples of identical legislation in the provinces suggests that it found the alleged concern artificial.

The J.C.P.C. summarized the provincial argument regarding the proper function of a court as follows:

[The reference provision] ... purports to create a Court ... as a branch of the Executive Government, an advisory committee for the purpose of

in the case of a judgment on an appeal to the Court, and any judges who differ from the opinion of the majority shall in like manner certify their opinions and their reasons.

(5) Where the question relates to the constitutional validity of any Act passed by the legislature of any province, or of any provision in any such Act, or in case, for any reason, the government of any province has any special interest in any such question, the attorney general of the province shall be notified of the hearing in order that the attorney general may be heard if he thinks fit.

(6) The Court has power to direct that any person interested or, where there is a class of persons interested, any one or more persons as representatives of that class shall be notified of the hearing on any reference under this section, and those persons are entitled to be heard thereon.

(7) The Court may, in its discretion, request any counsel to argue the case with respect to any interest that is affected and with respect to which counsel does not appear, and the reasonable expenses thereby occasioned may be paid by the Minister of Finance out of any moneys appropriated by Parliament for expenses of litigation.

14 Supra, note 6.

15 (U.K.) 30 \& 31 Vict., c. 3, reprinted in R.S.C. 1985, App. II, No. 5.

16 Supra, note 6, per Fitzpatrick C.J. 
advising the Executive upon any question which the Governor-General sees fit to refer to it. The giving of such advice is no part of the administration of the law, and it would necessarily include, inter alia, advice upon the legislation of the Imperial Parliament and of the various provincial Legislatures in Canada. So far from aiding in the administration of law it may easily be so used as to hamper and interfere with that administration. ... It was contended that it would or might be highly prejudicial to the administration of justice that the members of the Supreme Court should have been previously required to express opinions upon any such points until they actually arose for adjudication and had been argued before them. ... The obligation is inconsistent with the primary duty of the Court and the purpose for which it was created, namely, the administration of law. So far as that administration is impeded or overridden by the obligation imposed by [the provision] the Court ceases to be such a judiciary as the Constitution provides for. ${ }^{17}$

One is struck by the similarity between such arguments and those that are commonly raised in the United States against the perils of an unrestrained judiciary. The argument relies on a more rigid separation of powers, albeit in the clear furtherance of regional interests.

The J.C.P.C. first noted that the division of powers is exhaustive of all potential legislative authority in a given system. No power can be unavailable to both levels of government. While the Constitution's express words do not mention a judicial reference function, the Committee found that it clearly contemplates an institution which is capable of rendering such opinions - the Supreme Court — and allocates the power to establish that Court to the federal Parliament. The Committee dismissed the objection that a reference function is incompatible with judicial character, noting that such a power was well-established (if infrequently used) within British constitutionalism; and that numerous references already had been appealed to the Privy Council without such concerns having been raised.

Canadian courts, then, largely accepted the reference function as an appropriate extension of their duties. Rather than functioning only as a "check" on the executive branch, the judiciary was viewed as occasionally aligned ${ }^{18}$ with the executive branch.

$17 \quad I d$., at para. 4.

18 This continues to the present day, as for example in the Quebec Secession Reference the Supreme Court of Canada notes that the American conception of separation of powers does not find 
References do not engage the Court's remedial function. In Reference re Criminal Code (Canada), s. $873(A)^{19}$ a jurisdictional objection was couched on the grounds that the reference was actually an appeal of a criminal case. Although sympathetic to the provinces' concern, Justice Girouard concluded that "as our advice has no legal effect, does not affect the rights of parties, nor the provincial decisions, and is not even binding upon us", ${ }^{20}$ he had no objection to answering the questions. Justice Davies made the same point in Reference re References: "Being advisory only and not binding upon the body to whom they are given [the Governor General in Council] or upon the judges who give them they cannot be said to be in any way binding upon the judges of any of the provincial courts." 21

In 1910 the Chief Justice of Canada said that it was unthinkable that the Court would consider itself bound by its reference opinions. ${ }^{22}$ This, though, is precisely what happened. For decades the Supreme Court followed the decisions in earlier federal references with "undiscriminating zeal". ${ }^{23}$ Not until 1957 did the Supreme Court suggest that a reference opinion does not trigger the rule of res judicata with respect to future litigation in respect of the same subject. ${ }^{24}$ Of course, the absence of res judicata simply means that a case can proceed. It does not decide the persuasive value of the previous opinion. (Indeed, in the 1957 case the Supreme Court followed the rule laid down by the J.C.P.C.) Thus, by the time of the Patriation Reference, the notion that references were strictly advisory was correct only as a matter of pure constitutional law. Invariably references were treated as having the force of law. No government had ever treated a reference as "mere advice". 25

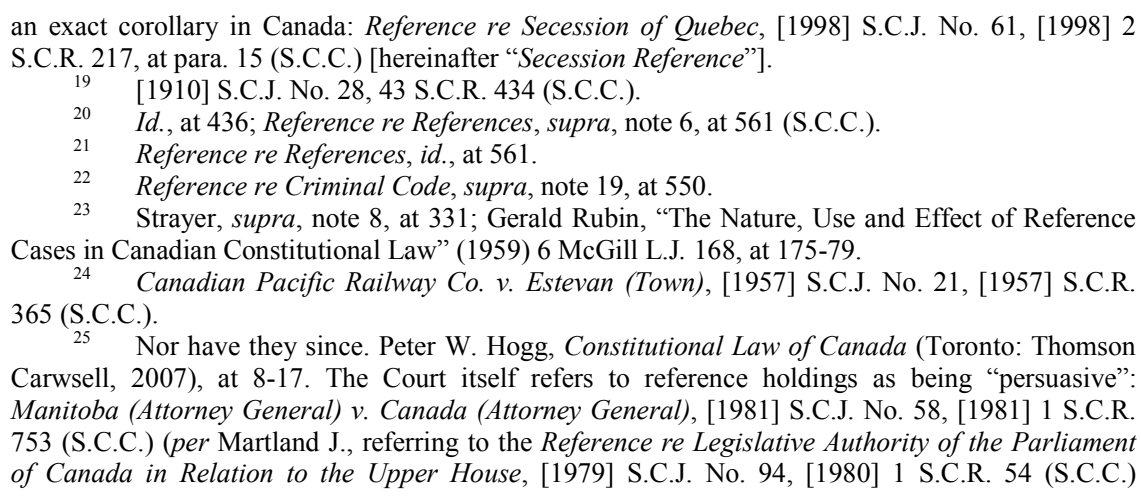

${ }_{25}$ Nor have they since. Peter W. Hogg, Constitutional Law of Canada (Toronto: Thomson Carwsell, 2007), at 8-17. The Court itself refers to reference holdings as being "persuasive": Manitoba (Attorney General) v. Canada (Attorney General), [1981] S.C.J. No. 58, [1981] 1 S.C.R. 753 (S.C.C.) (per Martland J., referring to the Reference re Legislative Authority of the Parliament of Canada in Relation to the Upper House, [1979] S.C.J. No. 94, [1980] 1 S.C.R. 54 (S.C.C.) 
In view of how the reference function evolved in Canada, it is inevitable that such opinions would receive deference even from courts. The 1891 amendments to the Supreme Court Act clarified the procedure in such a way as to render references virtually indistinguishable from cases. Notice was required, pleadings were made and, most importantly, reasons were given. Consider, for example, the Motor Vehicle Reference $^{26}$ (which struck down most absolute liability offences) and the judgment in Vaillancourt $^{27}$ (which struck down the felony murder rule). In terms of their content, structure and reasoning one is hard pressed to find many differences between them. In each, the Court appears to be performing the same function: identifying broad principles and applying them to produce a particular legal rule. Since the government is presumed to not want an unconstitutional law to stand once the Court has identified the "correct" legal answer, that would tend to settle the matter no matter the specific provenance of that conclusion.

Because they involve a question of the Executive's choosing, references are inconsistent with a strict separation of powers. ${ }^{28}$ And, since references are decided in the absence of a concrete case, it can be difficult to constrain their scope (normally, a power the Court enjoys when it sets constitutional questions). In Reference re References the J.C.P.C. noted "the mischief and inconvenience which might arise from an indiscriminate and injudicious use of the Act". ${ }^{29}$ Over time, the Supreme Court has articulated circumstances in which it may qualify or refuse to answer a question: insufficient factual context; ${ }^{30}$ mootness; ${ }^{31}$

[hereinafter "Senate Reference"]). Indeed, the fact that the Supreme Court Act no longer refers to such opinions as "advisory" might cast doubt upon the latter assertion.

${ }_{26}$ Reference re Motor Vehicle Act (British Columbia) S 94(2), [1985] S.C.J. No. 73, [1985] 2 S.C.R. 486 (S.C.C.) [hereinafter "Motor Vehicle Reference"].

${ }^{27}$ R. v. Vaillancourt, [1987] S.C.J. No. 83, [1987] 2 S.C.R. 636 (S.C.C.).

28 Given the special nature of references it must be recognized that the federal Cabinet enjoys a particular power - to refer questions to the Court, and treat the answer as binding — that align the executive and the Court, against the legislative branch and, indeed, against the provinces (although this latter concern was addressed early on in the Supreme Court Act, which now allows for appeals of provincial advisory opinions). The risk of inappropriate alignment between the executive and judiciary is somewhat mitigated by the authority of either house of the legislature to refer private bills to the Court: Supreme Court Act, R.S.C. 1985, c. S-26, s. 54. However, this power has fallen into disuse and, in any case, does not extend to government bills. Another possible approach is to treat references like the function currently performed by the British courts in respect of cases arising under the Human Rights Act 1998 (U.K.), 1998, c. 42, s. 4, where the courts' decisions are declaratory only.

${ }_{29} \quad$ Reference re References, supra, note 6, at para. 16 (P.C.).

30 Attorney General (Ontario) v. Attorney General (Canada), [1896] A.C. 348 (P.C.).

31 Reference re Amendment of Canadian Constitution, [1982] S.C.J. No. 101, [1982] 2 S.C.R. 793, 806 [hereinafter "Quebec Veto"]. 
lack of specificity; ${ }^{32}$ vagueness $;{ }^{33}$ and the risk that the opinion will produce legal uncertainty. ${ }^{34}$ The categories are rarely invoked, but, given that they are nowhere found in the Supreme Court Act, the Court in carving them out appears to be relying on separation of powers principles.

Thus, by 1981 the advisory opinion was firmly entrenched in Canada, and occupied a significant portion of the Court's docket. ${ }^{35}$ Early changes to the Supreme Court Act ensured that references would take the same form as cases. Certain parties enjoyed statutory rights of participation, and others could be granted standing. Evidence could be received, pleadings prepared, amici appointed and reasons would always be forthcoming. The opinions were also frequently divided, further belying any argument that references are different from cases.

\section{THE REFERENCE - SOME OBSERVATIONS}

By 1981 the provinces enjoyed a co-equal ability with Canada to initiate references. While provinces cannot refer questions directly to the Supreme Court, the Supreme Court Act permits an appeal as of right from reference opinions issued in provincial courts. At least half of all references in the Supreme Court concern provincially initiated questions. ${ }^{36}$

The provinces had long argued that their interests and standing in Confederation could be overborne by an indifferent or even hostile federal government. That government's decision to proceed unilaterally with a resolution to amend the Constitution could not have better illustrated the point. In considering their options, the provinces realized that a reference might be an effective political tool. ${ }^{37}$ They could bring the question of the appropriate conditions for constitutional change into the public spotlight. ${ }^{38}$ By duplicating proceedings, those provinces

32 Senate Reference, supra, note 25.

33 McEvoy v. New Brunswick (Attorney General), [1983] S.C.J. No. 51, [1983] 1 S.C.R. 704 (S.C.C.).

34 Reference re Same-Sex Marriage, [2004] S.C.J. No. 75, [2004] 3 S.C.R. 698, at paras. 10-12, 61-71 (S.C.C.).

$35 \quad$ Strayer cites 91 of 352 constitutional decisions between 1867 and 1986 - about onequarter of the total. Supra, note 8, at 311.

36 A survey I conducted of all references heard by the Supreme Court since 1980 confirms this assessment. I have not conducted a similar survey pre-1980, but a random canvassing of individual years confirms the pattern.

Roy Romanow, John Whyte \& Howard Leeson, Canada...Notwithstanding (Toronto: Thomson Carswell, 2007), at 155-63 [hereinafter "Romanow et al."].

$38 \quad$ Russell, supra, note 2. 
opposed to the Resolution could maximize the chances of a positive outcome on at least one of the questions. ${ }^{39}$ And, any reference would automatically reach the Supreme Court of Canada.

The provinces' reference powers allowed for flexibility in the wording and emphasis of the questions. Manitoba and Newfoundland's references involved the following questions in common:

Question 1 - If the amendments to the Constitution of Canada sought in the "Proposed Resolution for a Joint Address to Her Majesty the Queen respecting the Constitution of Canada", or any of them, were enacted, would federal-provincial relationships or the powers, rights or privileges granted or secured by the Constitution of Canada to the provinces, their legislatures or governments be affected and if so, in what respect or respects?

Question 2 - Is it a constitutional convention that the House of Commons and Senate of Canada will not request Her Majesty the Queen to lay before the Parliament of the United Kingdom of Great Britain and Northern Ireland a measure to amend the Constitution of Canada affecting federal-provincial relationships or the powers, rights or privileges granted or secured by the Constitution of Canada to the provinces, their legislatures or governments without first obtaining the agreement of the provinces?

Question 3 - Is the agreement of the provinces of Canada constitutionally required for amendment to the Constitution of Canada where such amendment affects federal-provincial relationships or alters the powers, rights or privileges granted or secured by the Constitution of Canada to the provinces, their legislatures or governments? ${ }^{40}$

Newfoundland submitted an additional question:

Question 4 - If Part V of the proposed resolution referred to in question 1 is enacted and proclaimed into force could

(a) the Terms of Union, including terms 2 and 17 thereof contained in the Schedule to the British North America Act, 1949 (12-13 George VI, c. 22 (U.K.)), or

(b) section 3 of the British North America Act, 1871 (34-35 Victoria, c. 28 (U.K.))

39 A reference also provided the advantage of a relatively expedited time frame, certainly in comparison to an outright legal challenge to patriation.

40 Patriation Reference, supra, note 1, at 762. 
be amended directly or indirectly pursuant to Part V without the consent of the Government, Legislature or a majority of the people of the Province of Newfoundland voting in a referendum held pursuant to Part $\mathrm{V} ?^{41}$

Perhaps unsurprisingly, Quebec's questions took a different form:

Question A - If the Canada Act and the Constitution Act, 1981 should come into force and if they should be valid in all respects in Canada would they affect:

(i) the legislative competence of the provincial legislatures in virtue of the Canadian Constitution?

(ii) the status or role of the provincial legislatures or governments within the Canadian Federation?

Question B - Does the Canadian Constitution empower, whether by statute, convention or otherwise, the Senate and the House of Commons of Canada to cause the Canadian Constitution to be amended without the consent of the provinces and in spite of the objection of several of them, in such a manner as to affect:

(i) the legislative competence of the provincial legislatures in virtue of the Canadian Constitution?

(ii) the status or role of the provincial legislatures or governments within the Canadian Federation? ${ }^{42}$

Already, an atmosphere of constitutional change had produced opinions on related subjects, most notably the Reference re Legislative Authority of the Parliament of Canada in Relation to the Upper House.$^{43}$ Released in 1980, the Senate Reference concerned a federal proposal to amend the Senate of Canada through ordinary legislation. In response to provincial protest the federal government referred several questions ${ }^{44}$ to the Supreme

$41 \quad I d$., at 763. I will not discuss this question further.

$42 \quad$ Id.

43 Supra, note 25.

$44 \quad I d$., at 57-58. The questions were as follows:

1. Is it within the legislative authority of the Parliament of Canada to repeal sections 21 to 36 of the British North America Act, 1867, as amended, and to amend other sections thereof so as to delete any reference to an Upper House or the Senate? If not, in what particular or particulars and to what extent?

2. Is it within the legislative authority of the Parliament of Canada to enact legislation altering, or providing a replacement for, the Upper House of Parliament, so as to effect any or all of the following:

(a) to change the name of the Upper House; 
Court. The government of Canada argued that the proposed changes lay within its exclusive authority under the former section 91(1) of the Constitution Act, 1867. ${ }^{45}$ Under that subsection Parliament enjoyed an amending power, but it was subject to numerous exceptions including any amendments to "matters coming within the classes of subjects by this Act assigned exclusively to the Legislatures of the provinces, or as

(b) to change the numbers and proportions of members by whom provinces and territories are represented in that House;

(c) to change the qualifications of members of that House;

(d) to change the tenure of members of that House;

(e) to change the method by which members of that House are chosen by

(i) conferring authority on provincial legislative assemblies to select, on the nomination of the respective Lieutenant Governors in Council, some members of the Upper House, and, if a legislative assembly has not selected such members within the time permitted, authority on the House of Commons to select those members on the nomination of the Governor General in Council, and

(ii) conferring authority on the House of Commons to select, on the nomination of the Governor General in Council, some members of the Upper House from each province, and, if the House of Commons has not selected such members from a province within the time permitted, authority on the legislative assembly of the province to select those members on the nomination of the Lieutenant Governor in Council,

(iii) conferring authority on the Lieutenant Governors in Council of the provinces or on some other body or bodies to select some or all of the members of the Upper House, or

(iv) providing for the direct election of all or some of the members of the Upper House by the public; or

(f) to provide that Bills approved by the House of Commons could be given assent and the force of law after the passage of a certain period of time notwithstanding that the Upper House has not approved them?

If not, in what particular or particulars and to what extent?

45 At the time, the provision read as follows:

1. The amendment from time to time of the Constitution of Canada, except as regards matters coming within the classes of subjects by this Act assigned exclusively to the Legislatures of the provinces, or as regards rights or privileges by this or any other Constitutional Act granted or secured to the Legislature or the Government of a province, or to any class of persons with respect to schools or as regards the use of the English or the French language or as regards the requirements that there shall be a session of the Parliament of Canada at least once each year, and that no House of Commons shall continue for more than five years from the day of the return of the Writs for choosing the House: provided, however, that a House of Commons may in time of real or apprehended war, invasion or insurrection be continued by the Parliament of Canada if such continuation is not opposed by the votes of more than one-third of the members of such House.

British North America (No. 2) Act, 1949 (U.K.), 13 Geo. VI, c. 81. It was repealed when the Constitution was repatriated, and replaced by s. 44 and the other amending procedures in Part V of the Constitution Act, 1982. 
regards rights or privileges ... granted or secured to the Legislature or the Government of a province". ${ }^{46}$

The Supreme Court found that an affirmative answer to the questions ${ }^{47}$ presupposed a federal power to abolish the Senate of Canada. This, Parliament could not do. ${ }^{48}$ The Court noted that section 91(1) was instituted in 1949 to obviate the need for the U.K. Parliament's consent on "federal "housekeeping"" matters that historically had been "obtained through a joint resolution of both Houses of Parliament and without provincial consent". ${ }^{49}$ The exceptions contained therein proved that amendments touching federal-provincial relations could not be achieved through unilateral federal action:

The legislation contemplated in [this reference] is of an entirely different character [than federal "housekeeping" matters]. While it does not directly affect ... federal and provincial legislative powers, it does envision the elimination of one of the two Houses of Parliament, and so would alter the structure of the federal Parliament to which the federal power to legislate is entrusted under s. 91 of the Act. ${ }^{50}$

More significant for the Patriation Reference was the Court's assertion that when a proposed constitutional amendment would affect provincial powers or status, history showed a high degree of provincial involvement. The Court noted with apparent approval four principles from a 1965 federal White Paper:

[First] ... that although an enactment by the United Kingdom is necessary to amend the British North America Act, such action is taken only upon formal request from Canada. No Act of the United Kingdom Parliament affecting Canada is therefore passed unless it is requested and consented to by Canada. Conversely, every amendment requested by Canada in the past has been enacted.

[Second,] that the sanction of Parliament is required. ... The procedure invariably is to seek amendments by a joint Address of the Canadian House of Commons and Senate to the Crown.

$46 \quad I d$

47 The Court also found that several of the sub-questions in Question 2 failed to present "a factual context in which to formulate a satisfactory answer". Senate Reference, supra, note 25, at 77. It therefore declined to answer questions 2(a), (c), (d) and (e)(i) to (iv).

$48 \quad$ Id., at 74.

$49 \quad$ Id., at 65.

$50 \quad I d$ 
[Third,] that no amendment to Canada's Constitution will be made by the British Parliament merely upon the request of a Canadian province. ...

[Fourth,] that the Canadian Parliament will not request an amendment directly affecting federal-provincial relationships without prior consultation and agreement with the provinces. This principle did not emerge as early as others but since 1907, and particularly since 1930, has gained increasing recognition and acceptance. The nature and the degree of provincial participation in the amending process, however, have not lent themselves to easy definition. ${ }^{51}$

The fourth principle would prove to be a point of contention in the Patriation Reference.

Turning now to the Patriation Reference itself, one is struck by the deep divisions it revealed among the justices. The Court considered an appeal from three provincial references, with questions that were carefully tailored to provoke maximum impact. Because none of the justices declined to play along, and because the Court clearly had its own internal divisions, the result was highly fractured, even confusing.

The Court considered three principal issues. ${ }^{52}$ Questions $1^{53}$ and $\mathrm{A}^{54}$ posed a deceptively simple question regarding the impact of the proposed constitutional amendments on provincial powers (variously referred to as "federal-provincial relations", "powers, rights or privileges", "legislative competence" and "status"). Declining to answer, the Manitoba Court of Appeal described Question 1 as "premature":

We ... face a real likelihood that the amendments sought in the Proposed Resolution may be altered, deleted, or supplanted by other amendments before the Resolution is deemed ready for transmission to Her Majesty. In this situation there is a danger that if we answer Question 1, with the proposed amendments in their present form, we may later find that we have answered matters no longer before us and have not answered matters that emerged in their stead. The Court should not be exposed to the risk of such an adventure in futility. ${ }^{55}$

51 Id., at 64, citing a White Paper published as the Hon. Guy Favreau, The Amendment of the Constitution of Canada (Ottawa: Queen's Printer, 1965) [hereinafter “White Paper"].

$52 \quad$ My schema excludes Question 4 of the Newfoundland Reference. It should be noted that the Court largely did so as well. Patriation Reference, supra, note 1, at 807-808.

53 Quoted in text accompanying note 40, supra.

54 Quoted in text accompanying note 42, supra.

55 Reference re Amendment of Constitution of Canada, [1981] M.J. No. 95, 117 D.L.R. (3d) 1, at para. 14 (Man. C.A.). 
The Newfoundland Court of Appeal, while noting the concerns, nonetheless answered the question ${ }^{56}$ as did the Quebec Court of Appeal. ${ }^{57}$ The Supreme Court did not spend much time at all on these questions, with all of the justices answering them in the affirmative. Nonetheless, the questions highlighted the fact that a major change to the Constitution of Canada was being pursued by the federal government that would negatively redound to provincial rights. The questions invoked the historic provincial concerns already discussed earlier in this paper - a potent argument in a number of regions across the country and even beyond.

The second issue concerned the federal government's authority to unilaterally pursue constitutional change that affects existing provincial powers. The issue was captured by Question 3 of the Manitoba/Newfoundland References, and part of Question B of the Quebec Reference. It was expressed most clearly as follows in Question 3:

Is the agreement of the provinces of Canada constitutionally required for amendment to the Constitution of Canada where such amendment affects federal-provincial relationships or alters the powers, rights or privileges granted or secured by the Constitution of Canada to the provinces, their legislatures or governments? ${ }^{58}$

It should be noted, though, that the question involves the ability of the federal government to initiate the amendment process by submitting resolutions to the U.K. Parliament. A majority of the Court clarified that it was dealing only with the federal government's discretion to make a request, not with any subsequent reaction to that request by Westminster. ${ }^{59}$ In other words, the majority confined the issue to the scope of Parliament's power to pass any resolution. It found no inherent limit, and

56 Newfoundland Constitutional Reference, [1981] C.A. 80, [1981] N.J. No. 212, 118 D.L.R. (3d) 1 (Nfld. C.A.).

57 Quebec Constitutional Reference, [1981] C.A. 80, 120 D.L.R. (3d) 385 (Que. C.A.).

58 Supra, note 40.

59 Patriation Reference, supra, note 1, at 774: Two observations are pertinent here. First, we have the anomaly that although Canada has international recognition as an independent, autonomous and self-governing state, as, for example, a founding member of the United Nations, and through membership in other international associations of sovereign states, yet it suffers from an internal deficiency in the absence of legal power to alter or amend the essential distributive arrangements under which legal authority is exercised in the country, whether at the federal or provincial level. When a country has been in existence as an operating federal state for more than a century, the task of introducing a legal mechanism that will thereafter remove the anomaly undoubtedly raises a profound problem. Secondly, the authority of the British Parliament or its practices and conventions are not matters upon which this Court would presume to pronounce. 
no limit on the power in the British North America Act ${ }^{60}$ or in any other Imperial Statute:

The stark legal question is whether this Court can enact by what would be judicial legislation a formula of unanimity to initiate the amending process which would be binding not only in Canada but also on the Parliament of the United Kingdom with which amending authority would still remain. It would be anomalous indeed, over-shadowing the anomaly of a constitution which contains no provision for its amendment, for this Court to say retroactively that in law we have had an amending formula all along, even if we have not hitherto known it. ... No one can gainsay the desirability of federal-provincial accord or acceptable compromise. That does not, however, go to legality. As Sir William Jowitt said, and quoted earlier, we must operate the old machinery perhaps one more time. ${ }^{61}$

The majority therefore concluded that there was no legal impediment to the federal government proceeding unilaterally.

Dissenting, Martland and Ritchie JJ. approached the question differently. Rather than asking whether it would constitute a breach of the law for Parliament to make the resolution, they asked whether Parliament possessed the legal authority to pass a resolution which would lead to fundamental changes to provincial powers. ${ }^{62}$ Noting the issue's "unique" character, they found such an action to be inconsistent with federalism. The federal government could not use its procedural advantage (namely, that it alone can "request" constitutional amendments) to bring about changes to provincial powers without the provinces' consent:

The effect of the position taken by the Attorney General of Canada is that the two Houses of Parliament have unfettered control of a triggering mechanism by means of which they can cause the B.N.A. Act to be amended in any way they desire. It was frankly conceded in argument that there were no limits of any kind upon the type of amendment that could be made in this fashion. In our opinion, this argument in essence maintains that the provinces have since, at the latest 1931, owed their continued existence not to their constitutional

\footnotetext{
$60 \quad$ Now the Constitution Act, 1867, supra, note 15.

61 Patriation Reference, supra, note 1, at 788.

$62 \quad$ Id., at 815.

63 Id. It so found, because "in the one hundred and fourteen years since Confederation the Senate and House of Commons of Canada have never sought, without the consent of the provinces, to obtain such an amendment nor, apparently, has that possibility ever been contemplated": $i d$.
} 
powers expressed in the B.N.A. Act, but to the federal Parliament's sufferance. ${ }^{64}$

In answering "no" - that Parliament lacked the power to pass the resolution at issue - the dissent expressly invoked the Supreme Court's duty to uphold the Constitution's basic structure:

This Court, since its inception, has been active in reviewing the constitutionality of both federal and provincial legislation. This role has generally been concerned with the interpretation of the express terms of the B.N.A. Act. However, on occasions, this Court has had to consider issues for which the B.N.A. Act offered no answer. In each case, this Court has denied the assertion of any power which would offend against the basic principles of the Constitution. ${ }^{65}$

There was thus a clear difference between the majority and dissenting opinions about the appropriate focus of Question 3 (and the relevant part of Question B) ${ }^{66}$ the extent to which role of the U.K. Parliament could be considered; and the extent to which extra-statutory considerations would apply.

Of course, the question about convention commanded the most attention. The issue was put forward in Question 2 of the Manitoba and Newfoundland References, and in the remaining part of Question B from the Quebec Reference. Here the Court also divided, but more narrowly. Only three justices who held there was no legal impediment also found that there was no convention requiring provincial consent. The remaining justices joined with Martland and Ritchie JJ. who concluded that there was indeed such a convention.

Interestingly, even the two justices dissenting on the convention issue decided to answer the question (while recognizing its challenges):

$[\mathrm{N}] \mathrm{o}$ legal question is raised in the questions under consideration in these reasons and, ordinarily, the Court would not undertake to answer them for it is not the function of the Court to go beyond legal determinations. Because of the unusual nature of these References and because the issues raised in the questions now before us were argued at some length before the Court and have become the subject of the reasons of the majority, with which, with the utmost deference, we cannot agree,

\footnotetext{
$64 \quad I d$., at $839-40$.

$65 \quad I d$., at 841.

66 These questions asked whether amendments affecting provincial powers require provinicial consent. The questions are reproduced in the text accompanying notes 40 and 42 , supra.
} 
we feel obliged to answer the questions notwithstanding their extralegal nature. ${ }^{67}$

Importantly, the dissent construed the questions to concern a convention of unanimous provincial consent:

Question 2 in the Manitoba and Newfoundland References refers without qualification to the "agreement of the provinces". Question B in the Quebec Reference uses the words "the consent of the provinces", also without qualification. The expressions "of the provinces" or "of the provinces of Canada" in this context and in general usage mean in plain English all of the provinces of Canada, and our consideration of the questions must be upon this basis. The Court, in our view, would not be justified in editing the questions to develop a meaning not clearly expressed. ${ }^{68}$

The dissent next argued that conventions have a different role in a federal versus a unitary state because of the greater dependency, in the former, on a strict equivalence between constitutionality and legality. Therefore:

[We cannot] agree with any suggestion that the non-observance of a convention can properly be termed unconstitutional in any strict or legal sense. ... (C)onstitutionalism in a unitary state and practices in the national and regional political units of a federal state must be differentiated from constitutional law in a federal state. Such law cannot be ascribed to informal or customary origins, but must be found in a formal document which is the source of authority, legal authority, through which the central and regional units function and exercise their powers. ${ }^{69}$

Asserting that a convention requires "that the parties concerned regard it as binding upon them", ${ }^{70}$ the dissent held that the relevant actors had not proceeded in such a fashion. ${ }^{71}$ Reviewing a history of 22 amendments, the dissent found that in only four cases was unanimous provincial consent sought or obtained. ${ }^{72}$

But what of the fourth principle from the 1965 White Paper mentioned in the Senate Reference - the principle that "the Canadian

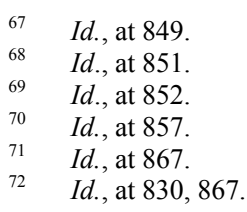


Parliament will not request an amendment directly affecting federalprovincial relationships without prior consultation and agreement with the provinces" ? $^{73}$ The dissent deemed this statement of little use since (a) the principle clearly did not contemplate unanimous consent and (b) the paper's author had noted elsewhere that none of the principles were "constitutionally binding in any strict sense" ${ }^{74}$

The majority on the convention issue (consisting now of six justices) reached a very different conclusion. First, those justices interpreted the question as having nothing to do with unanimity (notwithstanding that several of the provinces argued on precisely that basis):

It would have been easy to insert the word "all" into the question had it been intended to narrow its meaning. But we do not think it was so intended. The issue raised by the question is essentially whether there is a constitutional convention that the House of Commons and Senate of Canada will not proceed alone. The thrust of the question is accordingly on whether or not there is a conventional requirement for provincial agreement, not on whether the agreement should be unanimous assuming that it is required. ...

If the questions are thought to be ambiguous, this Court should not, in a constitutional reference, be in a worse position than that of a witness in a trial and feel compelled simply to answer yes or no.$^{75}$

The majority also considered whether the question ought to be answered at all. While acknowledging that conventions are highly political, it endorsed the following statement of Justice Freedman in the Manitoba Court of Appeal:

In my view, the request for a decision by this Court on whether there is a constitutional convention, in the circumstances described, that the Dominion will not act without the agreement of the Provinces poses a question that $\mathrm{i}[\mathrm{s}]$, at least in part, constitutional in character. It therefore calls for an answer, and I propose to answer it. ${ }^{76}$

The majority noted three criteria for identifying conventions: the existence of supportive precedents; a belief by the parties that they are bound by the precedents; and a reason for the rule. ${ }^{77}$ For the majority, the

Supra, note 51.

Patriation Reference, supra, note 1, at 870, 898.

$I d$., at 875 .

Id., at 884 .

Id., at 888 . 
precedents consisted of five previous amendments which directly affected federal-provincial relationships. ${ }^{78}$ In each case, the relevant change was accepted by the affected provinces. The majority also noted several "negative" examples where proposed amendments affecting specific provinces encountered objections from those provinces and did not proceed. ${ }^{79}$ As for cases where one province objected but the proposal nonetheless went forward, this at most counted against a convention of unanimity. ${ }^{80}$

The majority had little doubt that the relevant actors considered themselves bound by the precedents. They found the fourth principle recognized in the 1965 White Paper $^{81}$ to be particularly persuasive in this regard:

This statement is not a casual utterance. It is contained in a carefully drafted document which had been circulated to all the provinces prior to its publication and had been found satisfactory by all of them ... It was published ... under the authority of the federal Minister of Justice as member of a government responsible to Parliament, neither House of which, so far as we know, has taken issue with it. ${ }^{82}$

There was though significant uncertainty about the parameters of the convention itself. Indeed the White Paper asserted: "The nature and the degree of provincial participation in the amending process ... have not lent themselves to easy definition. ${ }^{, 83}$ No greater certainty had emerged in the intervening years. Importantly, the majority found that this did not pose a barrier to the convention - it simply complicated its contours. It was not the Court's role to provide that kind of certainty:

It would not be appropriate for the Court to devise in the abstract a specific formula which would indicate in positive terms what measure of provincial agreement is required for the convention to be complied with. Conventions by their nature develop in the political field and it

78 Id., at 891. The five amendments are: The British North America Act, 1930 (natural resources agreements between the Government of Canada and the Governments of Manitoba, British Columbia, Alberta and Saskatchewan); The Statute of Westminster, 1931; The British North America Act, 1940 (unemployment insurance); The British North America Act, 1951 (old age pensions); and The British North America Act, 1964 (pension supplementary benefits). Id., at 861-62.

79 Id., at 893-94.

$80 \quad$ Id. at $895-96$

81 Supra, note 51.

82 Patriation Reference, supra, note 1, at 900.

83 Supra, note 51, at 15. 
will be for the political actors, not this Court, to determine the degree of provincial consent required. ${ }^{84}$

Thus, the majority identified a convention of "substantial" rather than unanimous provincial consent. ${ }^{85}$ A situation in which eight provinces objected to an amendment that would affect their constitutional powers clearly fell short. The majority declined to further elaborate upon what else would fail to constitute "substantial consent".

Finally, it remains to consider the majority's assessment of the third criterion: the reason for the convention. Very much in line with provincial concerns and with the previous year's Senate Reference, the majority held that the purpose of the convention is to protect Canada's federal character and to "prevent the anomaly that the House of Commons and Senate could obtain by simple resolutions what they could not validly accomplish by statute". 86

The majority took pains to note that the substantive outcome of patriation - which would entrench an amending formula requiring substantial provincial consent ${ }^{87}$ - did not affect its constitutional bona fides. While Canada would remain a federal state, and even perhaps be improved from a provincial point of view, the process by which that end result was achieved would offend the requirement of substantial provincial consent. ${ }^{88}$ Thus the proposed Resolution to Amend the Constitution would be inconsistent with constitutional convention.

\section{LEGACY}

The Supreme Court's opinion in the Patriation Reference was a game-changer. The opinion affected the immediate circumstances under which patriation could be pursued. As Peter Russell ${ }^{89}$ and others ${ }^{90}$ have discussed, the federal government seized on the more favourable answer

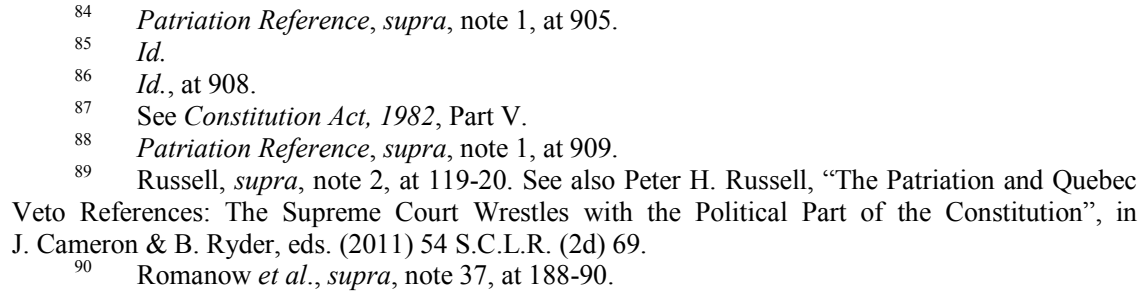


to the legal question but it could not fail to respond to the conclusion about convention. Renewed negotiation followed.

Apart from these first-order results, the Reference illustrates a number of other significant trends.

First, the Patriation Reference demonstrates the utility of strategic litigation. Such strategies were of course not new. ${ }^{91}$ But the concerted provincial effort dramatically affected the political landscape. While the reference proved a particularly effective litigation vehicle (since the various provinces could design the questions and initiate the litigation as they wished) it also illustrated the power of engaging with judicial processes. In the coming Canadian Charter of Rights and Freedoms ${ }^{92}$ era, strategic litigation would form an important (if not always successful) feature of the constitutional toolkit.

Second, the Supreme Court emerged as a critical agent of constitutional change. None of the justices shied away from answering the convention-related questions all the while admitting that they were venturing into unknown territory. The dissenting and minority opinions confidently asserted their authority - their duty, even - to provide an answer. One can be forgiven for musing that facing the tide of history the Court was loath to turn away. Of course, the justices were helped by the fact that their assistance had been requested, that the current situation was particularly complex and that judicial guidance arguably was appropriate. One sees a glimmer of the Court's future assertions that the "threat" to democracy posed by judicial review has largely been answered by the pre-commitment in the political community to accept a constitutional framework in which the judiciary plays a leading role..$^{93}$

The Reference posed questions concerning constitutional phenomena - conventions - which are quite injusticiable. Conventions involve the development of political custom and are self-executing by political actors to maintain popular legitimacy. As well, conventions do not take a recognizable legal form. The Supreme Court's resolution of these two formidable hurdles would find purchase in subsequent constitutional

91 See, e.g., Manitoba (Attorney General) v. Manitoba Egg and Poultry Assn., [1971] S.C.J. No. 63, [1971] S.C.R. 689 (S.C.C.). This reference was wholly fictional in the sense that the questions and proposed regulations were constructed by Manitoba in order to force the Supreme Court to provide answers to guide political negotiations surrounding the so-called "chicken and egg war".

Motor Vehicle Reference, supra, note 26, at para. 16; Vriend v. Alberta, [1998] S.C.J. No. 29, [1998] 1 S.C.R. 493, at paras. 129-135 (S.C.C.). 
jurisprudence. For example, the Court's high comfort level in dealing with the questions was borne out in its subsequent rejection of a political questions doctrine. ${ }^{94}$ Rather than considering whether a particular question might be "tainted" by political aspects, the Court accepted a very different starting point: in a system bound by constitutionalism and the rule of law, the judiciary may properly intervene any time a question has a legal or constitutional character regardless of its political nature. ${ }^{95}$ The Court also resisted a bifurcated approach to constitutional rules in which only some are amenable to judicial scrutiny. It adopted instead a narrative focused on structural legitimacy and systemic safeguards. This narrative would eventually re-emerge in the Court's eventual recognition of unwritten constitutional principles. ${ }^{96}$

The Patriation Reference is a powerful example of the purposive approach to constitutional interpretation. The foray into conventional rules is quite compatible with the notion that the Constitution's text cannot be solely determinative of all questions of a constitutional character. Admittedly, this approach was not new ${ }^{97}$ but I believe that the Reference gave it renewed vigour. The idea that a constitution exists for more than coordination and dispute resolution, that it expresses the basic character and qualities of a nation-state and that state actors are inhibited from taking action undermining that character, would prove to be an extremely powerful tool in both expanding the content of constitutional rules and, of course, cementing the Court's role as chief constitutional arbiter.

The Patriation Reference also exerted significant influence through the emergence of the "authoritative yet non-binding or less-than binding answer". The Reference is a perfect example of the power of the declaration. The bald assertion of something as constitutional fact without attendant remedies or juridical consequences permits the Court to exert tremendous influence without engaging in a power struggle. The Court was in a relatively safe position to consider all of the questions, because its reference function was by then so well-settled and accepted. This permitted the Court to state something as "law" without stating a clearly

94 Operation Dismantle Inc. v. Canada, [1985] S.C.J. No. 22, [1985] 1 S.C.R. 441, at paras. 52-54 (S.C.C.).

$95 \quad$ Secession Reference, supra, note 18, at para. 27.

96 Reference re Remuneration of Judges of the Provincial Court of Prince Edward Island, [1997] S.C.J. No. 75, [1997] 3 S.C.R. 3 (S.C.C.); Secession Reference, id. See, e.g., Edwards v. Canada (Attorney General), [1930] A.C. 124 (P.C.). 
binding rule. It did this, first, by recognizing a convention which admittedly had no legal force and, second, by providing an answer just binding enough to render the federal resolution unacceptable but sufficiently vague to leave future outcomes uncertain (since the convention referenced a standard rather than a clear rule).

Finally, it is possible that the Reference served as a cautionary tale. The Court was quite divided and this provided fodder for arguments that individual justices had acted in a partisan manner. ${ }^{98}$ The Court may consciously have sought to avoid this problem in subsequent opinions. The analysis necessarily is tentative because the size of the candidate pool is so small. But it is worth noting that in four equally weighty references - Quebec Veto, ${ }^{99}$ Manitoba Language Rights, ${ }^{100}$ Quebec Secession ${ }^{101}$ and Same-sex Marriage ${ }^{102}$ - the Court spoke per curiam.

To conclude, the Patriation Reference merged aspects of our history and legal tradition with an uncertain future. The Supreme Court emerged as a profoundly important constitutional actor. The immediate acquiescence by political actors in the majority's ruling (notwithstanding serious misgivings about its reasoning) paved the way for other critical questions to find their way onto the Court's docket. The most immediate result was the Quebec Veto Reference the following year, the impact of which is still felt today. Somewhat ironically, the reference function itself would be overtaken by traditional constitutional litigation, as the Constitution Act, $1982^{103}$ provided additional causes of action. But whether one considers the references or the myriad cases that have followed, the force of the Patriation Reference remains definitive.

98 Mandel, supra, note 2, at 30.

99 Supra, note 31. (S.C.C.).

Reference re Manitoba Language Rights, [1985] S.C.J. No. 36, [1985] 1 S.C.R. 721

Secession Reference, supra, note 18.

Reference re Same-Sex Marriage, supra, note 34.

Schedule B to the Canada Act 1982 (U.K.), 1982, c. 11. 